\title{
The above literatures all proved that the trace elements in the lipid soluble extracts of ants also played a role in the anti- cadmium poisoning.
}

\author{
XIA Qiubo ${ }^{1}$, GUAN Nannan ${ }^{1}$, LU Huidi ${ }^{1}$, WANG Zining ${ }^{2}$, ZHANG Chunyue ${ }^{1}$, WANG Zihan ${ }^{1}$, ZHANG Qiang $^{3 *}$, CHENG \\ Guangdong ${ }^{1 *}$ \\ ${ }^{1}$ College of Life Science, Jiamusi University, Heilongjiang province, Jiamusi 154007, China \\ ${ }^{2}$ College of Life Science, Northeast Agricultural University, Harbin, Heilongjiang, 150030, China \\ ${ }^{3}$ School of Biology and Food Engineering, Guangdong University of Petrochemical Technology, 525000 Maoming, China
}

\begin{abstract}
In order to study the quasi black prickly ant extracts antioxidant mechanism, test the completely random method is adopted to 160 rats, and randomly divided into 8 groups, divided into control group, cadmium poisoning group, cadmium and extracts from petroleum ether to black prickly ant group (divided into high, medium and low dose group), cadmium to higher doses of anhydrous ethanol extracts from black prickly ant group, higher dose of petroleum ether to black prickly ant extract group, only higher doses of anhydrous ethanol extracts from black prickly ant group. The mice were fed for 21 days, and the clinical symptoms of the mice were observed every day. On the 22 nd day, the liver, spleen, kidney and sexual organs of the mice were dissected and separated, and the organ coefficients of the mice were calculated. After grinding treatment, the contents of MDA, SOD, CAT and T-AOC in kidney and spleen of mice were determined according to the instructions of the kit. Results showed that the mice of the sex organs of liver, spleen, kidney, organ coefficient were elevated compared with control group $(\mathrm{P}<0.05)$, cadmium poisoning group mice kidney, spleen MDA levels were elevated compared with control group $(\mathrm{P}<0.05)$, cadmium poisoning group mice kidney, spleen SOD, T-AOC,CAT content decreased $(\mathrm{P}<0.05)$, The results indicated that the lipid soluble extract of C. nigra had antioxidant ability, and the low and medium dose of lipid soluble extract of C. nigra had less cadmium toxicity than the high doseThe curative effect in mice was remarkable and the anti-inflammatory function was achieved.
\end{abstract}

\section{Introduction.}

Polyrhachis nigricans (also known as Polyrhachis dingtu) is a kind of black ant. Polyrhachis nigricans mainly distributes in Guizhou, Yunnan, Guangxi, Jilin and other places. Polyrhachis nigricans contains a variety of effective chemical components. Chemical analysis shows that the protein content of Polyrhachis nigricans is more than $50 \%$. It also contains a variety of vitamins, amino acids and a large number of trace elements The content of zinc is extremely rich in the soil ${ }^{[1]}$. The pharmacological and immune experiments of Polyrhachis nigra show that it has many functional activities, such as anti gout, anti-aging, immune regulation, anti fatigue, regulating blood sugar and antioxidation $\left.{ }^{[2}\right]$. At the same time, Polyrhachis nigra is the only ant approved by the Ministry of health with the same drug and food origin, known as "micro animal nutrition treasure house" and "natural drug processing factory". Ant extract and ant products can increase the immune function, promote the development of thymus, spleen and other organs, increase the white blood cells in the blood, increase the production of antibodies by cells

\footnotetext{
${ }^{*}$ Corresponding author: ${ }^{*}$ email: chengguangdong@jmsu.edu.cn
}

3*email: zhangqiang@gdupt.edu.cn and the level of antibodies in serum ${ }^{[3]}$. Xu Shuixiang et al. ${ }^{[4]}$ have studied the inhibitory effect of ant fatty acid extract on leukemia and lung cancer cells, and have confirmed that cancer cells are significantly inhibited. In this study, the same concentration of cadmium chloride and different doses of ant extract were injected into groups, and the effects of ant extract on the antioxidant index of different organs of mice under cadmium chloride pollution were determined to explore the mechanism of ant extract against cadmium chloride induced poisoning in mice, so as to lay a theoretical foundation for the application of ants and provide an effective strategy for the development of new drugs.

\section{Materials and Methods}

\subsection{Experimental animals}

Kunming mice were purchased from Experimental Animal Center of Jiamusi University. 


\subsection{Drug}

$\mathrm{CdCl} 2$ with $98.50 \%$ purity is produced by Shanghai Zhanyun Huagong Co.,Ltd

\subsection{Main ReagentsMain kits}

Total superoxide dismutase(T-SOD)test box(Batch No.A001-1-2), protein Quantitative test box (Batch No.A045-2-2), catalase (CAT) test box (Batch No.A0071-1) were purchased from Beijing Solibol Technology Co.,Ltd.Malondialdehyde (MDA)Test Kit (Batch No.A003-1-2), Total Antioxidant Capacity(T-AOC) Kit(Batch No.A015-1-2) and Hydroxyl Radical Test Kit (Batch No.A018-1-1)were all purchased from Nanjing Jiancheng Institute of Biological Engineering.

\subsection{Main Instruments Visible}

Spectrophotometer was purchased from Shanghai Analytical Instrument FactoryThe centrifuge was purchased from Shanghai Centrifuge Instrument Co.,LtdThe adjustable temperature electric heating kit is purchased from Shandong Chenghualu Electric Heating Instrument Co., LtdDigital display constant temperature water bath is purchased from Shandong Chenghualu Electric Heating Instrument Co.,Ltd.

\subsection{Grouping and administration of experimental animals}

160 kunming mice were randomlydivided into 8 groups, the grouping situation as follows: 1 group as the control group,two groups of cadmium poisoning group, 3 group for cadmium higher doses of the extracts from petroleum ether to black prickly ant group, four groups of cadmium to higher doses of anhydrous ethanol extracts from black prickly ant group, 5 for the higher dose of petroleum ether to only black prickly ant extract group, 6 for the higher dose of anhydrous ethanol to black prickly ant extract group, 7 in cadmium dose with China petroleum ether to black prickly ant extract group, 8 for cadmium and low doses of petroleum ether extracts from black prickly ant group.Twenty mice in each group (half male and half female) were given intraperitoneal injection and gavage each day, among which group 1 was injected and gavaged with normal saline of equal measure; the other groups injected with cadmium chloride were injected with $0.078 \mathrm{~mL} / \mathrm{g}$ according to body weight; the group without cadmium chloride was injected with normal saline of equal measure. The high-dose extract group was given $0.3 \mathrm{ml} / 20 \mathrm{~g}$ by gavage, the medium-dose extract group was given about $0.2 \mathrm{ml} / 20 \mathrm{~g}$ by gavage, the lowdose extract group was given about $0.1 \mathrm{ml} / 20 \mathrm{~g}$ by gavage, and the group without extract was given the same dose of normal saline. 20 mice in each group were fed under natural light, with sufficient feed and drinking water, and the temperature in the laboratory was about $22^{\circ} \mathrm{C} .21$ days later, all mice were sacrificed and performed necropsy. The liver, spleen, lung, kidney and sex organs were taken. The changes of the mice organs were observed and the organ index was calculated, and then the test box was used for the test.

\subsection{Determination of oxidative activity of the extracts of C.nigricans on various of cadminum- contaminated mice}

The thymus and spleen of mice were removed and killed 21 days later. The residual blood was dried with filter paper and weighed. The index of thymus and spleen was calculated.The $10 \%$ tissue homogenate was prepared by machine homogenate according to the kit instructions.Determination of MDA, T-SOD activity, CAT, T-AOC, reagent preparation, operation and calculation were carried out according to the test box instructions.2.3 Statistical analysis of data SPSS 18.0 software was used for statistical analysis of all experimental data, and the experimental data was represented as "mean \pm standard error". One-way variance analysis was used to obtain the data, and $\mathrm{P}<0.05$ indicated statistically significant differences.

\section{Results and analysis}

\subsection{Clinical symptoms of Cadmium-induced mice induced by Extract of C.nigricans}

The experimental study found that the mice in the cadmium poisoning group had reduced food intake and water intake, rough fur, sweating, depression, fecal pollution in the anus and tail region, irritability and so on. The other groups were the same as the normal group.

\subsection{Effect ofExtract of Polycoccus nuciformis on the coefficient of various organs in mice poisoned by cadmium}

As can be seen from the table, there was a significant difference in liver organ coefficient between the two groups and the control group $(\mathrm{P}<0.05)$, while there was no statistical significance in other intervention groups. There were significant differences between the intervention group and the two groups $(\mathrm{P}<0.05)$.

In terms of renal organ coefficient, compared with the control group, groups 2, 3, 4, 7 and 8 were all larger and statistically significant, and significantly different from groups 4, 5, 6 and 8 in the two groups $(\mathrm{P}<0.05)$.In terms of spleen organ coefficient, there was significant difference between the two groups and the control group $(\mathrm{P}<0.05)$.There were significant differences between the intervention group and the two groups $(\mathrm{P}<0.05)$.As for lung organ coefficient, there was no significant change among all groups, which was not statistically significant.There were significant differences in the coefficient of sexual organs between the two groups compared with the control group. There were significant differences between the intervention group and the two groups $(\mathrm{P}<0.05)$. 
Table 1 effect of extract on organ coefficient of cadmium poisoned mice (Mean $\pm \mathrm{SD}, \mathrm{g})$

\begin{tabular}{|c|c|c|c|c|c|}
\hline $\begin{array}{c}\text { Grou } \\
\text { p }\end{array}$ & liver & Kidney & Spleen & Lung & $\begin{array}{c}\text { Sexual } \\
\text { organ }\end{array}$ \\
\hline 1 & $\begin{array}{c}5.52 \pm 0.2 \\
6\end{array}$ & $\begin{array}{c}1.32 \pm 0.0 \\
3\end{array}$ & $\begin{array}{c}0.43 \pm 0.0 \\
2 \\
\end{array}$ & $0.73 \pm 0.03$ & $0.65 \pm 0.01$ \\
\hline 2 & $\begin{array}{c}5.69 \pm 0.0 \\
3^{\mathrm{a}} \\
\end{array}$ & $\begin{array}{c}1.44 \pm 0.0 \\
2^{\mathrm{a}}\end{array}$ & $\begin{array}{c}0.53 \pm 0.0 \\
2^{\mathrm{a}}\end{array}$ & $0.73 \pm 0.01$ & $0.70 \pm 0.03^{\mathrm{a}}$ \\
\hline 3 & $\begin{array}{c}5.53 \pm 0.0 \\
5\end{array}$ & $\begin{array}{c}1.35 \pm 0.0 \\
3\end{array}$ & $\begin{array}{c}0.43 \pm 0.0 \\
2\end{array}$ & $0.75 \pm 0.03$ & $0.64 \pm 0.03$ \\
\hline 4 & $\begin{array}{c}5.42 \pm 0.0 \\
3^{\mathrm{b}} \\
\end{array}$ & $\begin{array}{c}1.36 \pm 0.0 \\
2^{\mathrm{b}}\end{array}$ & $\begin{array}{c}0.42 \pm 0.0 \\
2^{\mathrm{b}}\end{array}$ & $0.73 \pm 0.03$ & $0.66 \pm 0.01^{\mathrm{b}}$ \\
\hline 5 & $\begin{array}{c}5.52 \pm 0.0 \\
7^{\mathrm{b}} \\
\end{array}$ & $\begin{array}{c}1.32 \pm 0.0 \\
1^{\mathrm{b}} \\
\end{array}$ & $\begin{array}{c}0.41 \pm 0.0 \\
2^{\mathrm{b}} \\
\end{array}$ & $0.71 \pm 0.04$ & $0.64 \pm 0.01^{b}$ \\
\hline 6 & $\begin{array}{c}5.47 \pm 0.0 \\
8^{\mathrm{b}} \\
\end{array}$ & $\begin{array}{c}1.34 \pm 0.0 \\
2^{\mathrm{b}} \\
\end{array}$ & $\begin{array}{c}0.42 \pm 0.0 \\
2^{\mathrm{b}} \\
\end{array}$ & $0.73 \pm 0.02$ & $0.63 \pm 0.03^{\mathrm{b}}$ \\
\hline 7 & $\begin{array}{c}5.40 \pm 0.0 \\
5^{\mathrm{a}} \\
\end{array}$ & $\begin{array}{c}1.34 \pm 0.0 \\
2\end{array}$ & $\begin{array}{c}0.42 \pm 0.0 \\
3\end{array}$ & $0.74 \pm 0.04$ & $0.65 \pm 0.01$ \\
\hline 8 & $\begin{array}{c}5.49 \pm 0.0 \\
3^{\mathrm{b}}\end{array}$ & $\begin{array}{c}1.35 \pm 0.0 \\
1^{\mathrm{b}}\end{array}$ & $\begin{array}{c}0.44 \pm 0.0 \\
4^{\mathrm{b}}\end{array}$ & $0.74 \pm 0.04$ & $0.65 \pm 0.02^{\mathrm{b}}$ \\
\hline
\end{tabular}

Note: A represents comparison with group $1 \mathrm{P}<0.05$, and $\mathrm{B}$ represents comparison with group $2 \mathrm{P}<0.05$. For control group 1, no. 2 for cadmium poisoning group, 3 for the higher dose of petroleum ether to only black prickly ant extract group 4 extensions for cadmium dose the extracts from petroleum ether to black prickly ant group, 5 in cadmium dose with China petroleum ether to black prickly ant extract group, 6 for cadmium with low doses of petroleum ether extracts from black prickly ant group, 7 for the higher dose of anhydrous ethanol to

Table 2 Comparison of MDA, SOD, T-AOC and CAT in kidney and spleen between groups

\begin{tabular}{|c|c|c|c|c|c|c|c|c|}
\hline Group & $\begin{array}{l}\text { Kidney } \\
\text { MDA }\end{array}$ & $\begin{array}{l}\text { Spleen } \\
\text { MDA }\end{array}$ & $\begin{array}{l}\text { Kidney } \\
\text { SOD }\end{array}$ & Spleen SOD & $\begin{array}{l}\text { Kidney T- } \\
\text { AOC }\end{array}$ & $\begin{array}{l}\text { Spleen T- } \\
\text { AOC }\end{array}$ & $\begin{array}{c}\text { Kidney } \\
\text { CAT }\end{array}$ & $\begin{array}{l}\text { Spleen } \\
\text { CAT }\end{array}$ \\
\hline 1 & $\begin{array}{c}34.7 \\
\pm 0.93 \\
\end{array}$ & $\begin{array}{l}15.63 \\
\pm 0.76\end{array}$ & $\begin{array}{c}155.09 \\
\pm 2.86 \\
\end{array}$ & $\begin{array}{c}217.78 \\
\pm 6.39 \\
\end{array}$ & $\begin{array}{c}7.34 \\
\pm 1.06 \\
\end{array}$ & $\begin{array}{c}9.21 \\
\pm 0.78 \\
\end{array}$ & $\begin{array}{c}7.34 \\
\pm 1.06 \\
\end{array}$ & $\begin{array}{l}99.13 \\
\pm 4.46 \\
\end{array}$ \\
\hline 2 & $\begin{array}{c}41.01 \\
\pm 2.20^{\mathrm{a}} \\
\end{array}$ & $\begin{array}{c}21.19 \\
\pm 0.63^{\mathrm{a}} \\
\end{array}$ & $\begin{array}{l}140.49 \\
\pm 2.15^{\mathrm{a}} \\
\end{array}$ & $182.09 \pm 6.41^{\mathrm{a}}$ & $\begin{array}{c}6.56 \\
\pm 0.38^{\mathrm{a}} \\
\end{array}$ & $\begin{array}{c}7.99 \\
\pm 0.71^{\mathrm{a}} \\
\end{array}$ & $6.56 \pm 0.38^{\mathrm{a}}$ & $89.87 \pm 4.01^{\mathrm{a}}$ \\
\hline 3 & $\begin{array}{c}32.03 \\
\pm 0.81^{\mathrm{b}} \\
\end{array}$ & $\begin{array}{c}15.22 \\
\pm 0.69^{\mathrm{b}} \\
\end{array}$ & $\begin{array}{l}162.45 \\
\pm 5.49^{\mathrm{b}} \\
\end{array}$ & $\begin{array}{c}226.03 \\
\pm 4.5^{\mathrm{b}}\end{array}$ & $\begin{array}{c}8.23 \\
\pm 0.90^{\mathrm{b}} \\
\end{array}$ & $9.51 \pm 0.32^{b}$ & $8.23 \pm 0.90^{\mathrm{b}}$ & $99.97 \pm 1.78^{b}$ \\
\hline 4 & $\begin{array}{c}34.56 \\
\pm 1.95^{\mathrm{b}} \\
\end{array}$ & $\begin{array}{c}16.46 \\
\pm 0.54^{\mathrm{b}} \\
\end{array}$ & $\begin{array}{l}162.84 \\
\pm 3.48^{\mathrm{b}} \\
\end{array}$ & $\begin{array}{l}228.34 \\
\pm 7.64^{\mathrm{b}} \\
\end{array}$ & $\begin{array}{c}7.79 \\
\pm 0.59^{\mathrm{b}} \\
\end{array}$ & $8.29 \pm 2.34$ & $7.79 \pm 0.59^{b}$ & $99.43 \pm 3.00^{\mathrm{b}}$ \\
\hline 5 & $\begin{array}{l}34.43 \\
\pm 0.57 \\
\end{array}$ & $\begin{array}{l}16.84 \\
\pm 0.50 \\
\end{array}$ & $\begin{array}{l}149.75 \\
\pm 6.72 \\
\end{array}$ & $\begin{array}{c}223.40 \\
\pm 2.72 \\
\end{array}$ & $\begin{array}{c}7.37 \\
\pm 0.25 \\
\end{array}$ & $8.60 \pm 0.26$ & $7.37 \pm 0.25$ & $99.37 \pm 2.21$ \\
\hline 6 & $\begin{array}{l}33.42 \\
\pm 1.16 \\
\end{array}$ & $\begin{array}{l}15.50 \\
\pm 0.41\end{array}$ & $\begin{array}{c}155.04 \\
\pm 1.76\end{array}$ & $\begin{array}{c}226.08 \\
\pm 3.77\end{array}$ & $7.09 \pm 0.41$ & $8.54 \pm 0.36$ & $7.09 \pm 0.41$ & $97.12 \pm 1.96$ \\
\hline 7 & $\begin{array}{c}28.77 \\
\pm 1.85^{\mathrm{b}} \\
\end{array}$ & $\begin{array}{c}13.35 \\
\pm 0.71^{\mathrm{b}} \\
\end{array}$ & $\begin{array}{l}157.50 \\
\pm 2.38^{\mathrm{b}}\end{array}$ & $\begin{array}{l}225.63 \\
\pm 5.87^{\mathrm{b}} \\
\end{array}$ & $8.35 \pm 0.19^{\mathrm{b}}$ & $9.63 \pm 0.42^{\mathrm{b}}$ & $8.35 \pm 0.19^{b}$ & $98.05 \pm 1.50^{\mathrm{b}}$ \\
\hline 8 & $\begin{array}{c}27.39 \\
\pm 0.92^{\mathrm{b}}\end{array}$ & $\begin{array}{c}11.52 \\
\pm 0.39^{\mathrm{b}} \\
\end{array}$ & $\begin{array}{l}163.37 \\
\pm 3.50^{\mathrm{b}} \\
\end{array}$ & $\begin{array}{r}237.95 \\
\pm 3.52^{\mathrm{b}} \\
\end{array}$ & $8.29 \pm 0.26^{\mathrm{b}}$ & $10.46 \pm 0.23^{b}$ & $\begin{array}{c}8.29 \\
\pm 0.26^{\mathrm{b}} \\
\end{array}$ & $98.40 \pm 2.60^{b}$ \\
\hline
\end{tabular}

Note: 1, for the control group, 2 for cadmium poisoning group, 3 cadmium higher doses of petroleum ether, 4 for cadmium higher doses of anhydrous ethanol extracts from black prickly ant group, 5 only higher doses of the extracts from petroleum ether to black prickly ant group, 6 for the higher dose of anhydrous ethanol to black prickly ant extract group, 7 in cadmium dose with China petroleum ether to black prickly ant extract group, 8 for cadmium and low doses of petroleum ether extracts from black prickly ant group. A is compared to group 1 $\mathrm{P}<0.05$, b is compared to group $2 \mathrm{P}<0.05$.

\section{Conclusions}

In terms of the organ coefficients of mice, the indexes of liver, kidney and spleen in mice were consistent with the trend in the literature of Zhai Jinxia ${ }^{[5]}$. The weight of viscera in the cadmium poisoning group would increase, black prickly ant extract group, 8 for cadmium higher doses of anhydrous ethanol extracts from black prickly ant group.

\subsection{Effects of $M$. nigricans extracts on the contents of MDA, SOD, T-AOC and CAT in kidney and spleen tissues of mice poisoned by cadmium}

As can be seen from Table 2, compared with Group 1, MDA in both kidney and spleen of Group 2 was significantly increased, and the difference was statistically significant.In group 2, SOD, T-AOC, CAT of kidney and spleen were significantly decreased, and all of them had statistical significance $(\mathrm{P}<0.05)$; Compared with group 2, the renal MDA and spleen MDA in groups $3,4,7$ and 8 decreased to varying degrees. Overall, the renal MDA and spleen MDA in groups 7 and 8 decreased significantly.Compared with group 2, SOD, T-AOC, CAT in kidney and SOD, TAOC, CAT in spleen in groups $3,4,7$ and 8 were significantly increased, and the differences were statistically significant. while there was a significant difference between the intervention group and the cadmium poisoning group.The sexual organ index is consistent with Yang Zisheng's conclusion ${ }^{[6]}$. The weight of visceral organs in the cadmium poisoning group will increase, while there will be a significant difference between the intervention group and the cadmium poisoning group.Wang Lele ${ }^{[7]}$ has also proved that low doses of selenium are effective against cadmium poisoning, The above literatures all proved that the trace elements in the lipid soluble extracts of ants also played a role in the anti-cadmium poisoning.

Cadmium mainly accumulated in the kidney and spleen, so this article from the analysis point of view of the two organs antioxidant indicators, through analyzing the antioxidant fat-soluble extracts antioxidant capacity may with quasi black prickly ant fat-soluble extract contains a variety of antioxidants, such as unsaturated 
fatty acids (oleic acid, linoleic acid, etc.), a fat-soluble vitamin, protein, trace elements and so on, this experimental study shows that compared with cadmium poisoning group intends to black prickly ant fat-soluble extract could reduce the content of MDA, increase the content of antioxidant enzymes, can achieve the result of antioxidant.

\section{Acknowledgements}

Scientific research projects of basic scientific research business expenses of Heilongjiang Provincial Colleges and universities (2020-KYYWF-0231)

Educational research project of Jiamusi University (JKA2014-023)

Jiamusi University President innovation and entrepreneurship fund project (XZYF2019-25)

Projects of Talents Recruitment of GDUPT (519030)

The Focus Areas of Ordinary Colleges and Universities Special in Guangdong Province (2020ZDZX1027)

\section{References}

1. YANG Zhixin,LIU Hui,XU Guijun,et al.Research progress on chemical constituents, pharmacological action and clinical application of black ant [J]. China Pharmacy,2020,31(09):1148-1152.(in Chinese)

2. Li Dongmei,Wei Guining.Progress in pharmacological studies on active components of the Formicidae [J]. Chinese Journal of Pharmacology and Toxicology,2019,33(10):831.(in Chinese)

3. TANG Jianjun. Studies on the chemical constituents and pharmacological activities of Polytidae nymphylla and Cricephalus nigricans [D].Chengdu University of Traditional Chinese Medicine,2015.(in Chinese)

4. XU Shuixiang,LI Yuezhong, TANG Liang, et al.Inhibitory effect of Chrysomya megacephala extract on leukemia and lung cancer cells.Pharmaceutical Biotechnology, 2008,15 (4):286-288.(in Chinese)

5. ZHAI Jinxia, FENG Yajuan, ZHANG Zhaoxiang, et al.Study on the antioxidant capacity of subchronic cadmium exposed mice $[\mathrm{J}]$. China Journal of Industrial Medicine,2009,22(02):98-100.(in Chinese)

6. YANG ZiSheng.Study on the protective effect of Polygonum flavescens on testicular injury in mice infected with cadmium [D]. Anhui Agricultural University,2018. (in Chinese)

7. WANG LeLe. A preliminary study on the effect of selenium on cadmium induced renal pathological injury in rats and the mechanism of toxicity [D].Fourth Military Medical University,2017. (in Chinese) 